Biswas, S. and S.K. Chatterjee (1991). Insecta: Coleoptera: Scarabaeidae, State Fauna Series 1: Fauna of Orissa. Zoological Survey of India (Part 3): 243-262.

Chandra, K. and R.K. Singh (Communicated). On a collection of scarabaeid beetles from Pachmarhi Biosphere Reserve (Hoshangabad: Madhya Pradesh). Rec. Zool. Surv. India.

Dalla Torre, K.W. (1912-13). Coleopterrourum Catalogus (W. Junk). Scarabaeidae, Melolonthinae, pars 45, 47, 49, 50.

Fincher, G.T. (1981). The potential value of dung beetles in pasture system. J. Ga Ent. Soc. 16(2): 316-333.

Kuijten, P.J. (1983). Revision of the genus Hybosorus Macleay (Coleoptera: Scarabaeidaae: Hybosorinae). Zool. Verh. Leiden, 203: 149.

Machastschke, J.W. (1972). Coleopterorum Catalogus, (W. Junk), Scarabaeoidea, Melolonthidae, Rutelinae.

Newton, P.N. and J.C. Malcolm (1985). Dung and dung beetles in Kanha Tiger Reserve, Central Indian Highlands. J. Bombay nat. Hist. Soc. 85: 218-220.

NOTE ZOOS' PRINT JOURNAL 15(11): 362

\section{LARGE CONGREGATION OF ROOSTING HARRIERS IN SECUNDERABAD, ANDHRA PRADESH}

\section{Bhargavi Srinivasulu ${ }^{1}$ and C. Srinivasulu ${ }^{2}$}

${ }^{1}$ Senior Research Fellow, ${ }^{2}$ Senior Research Fellow (Wildlife) Wildlife Biology Section, Department of Zoology, Osmania University, Hyderabad, Andhra Pradesh 500007, India

${ }^{1}$ E-mail: bhargavi.srinu@usa.net.

${ }^{2}$ E-mail:masawa@satyam.net.in

On 17 December 1999, at about $1730 \mathrm{hr}$, while observing roosting harriers in a grassland in northern Secunderabad ( $c^{\prime} 17^{0} 26^{\prime}$ $17^{\circ} 27^{\prime} \mathrm{N} \& 78^{0} 27^{\prime}-78^{\circ} 28^{\prime} \mathrm{E}$ ) we noted large congregation of 570730 individuals of four species of harriers (Table 1) in 18 roosting spots. During our regular observation spanning seven years (1993-94 to 1999-2000) such a large congregation was seldom recorded. At the most 200-300 roosting individuals were noted. Altogether, five species of harriers, namely - Eurasian Marsh Harrier (Circus aeruginosus), Montagu's Harrier (Circus pygargus), Pallid Harrier (Circus macrourus), Pied Harrier (Circus melanoleucos) and Hen Harrier (Circus cyaneus) have been recorded roosting here (pers. observ.; Kannaiah \& Ganesh, 1995). The last species was the rarest, while Kannaiah \& Ganesh (1995) reported Pied Harrier to be the rarest during their observation.

The harriers displayed the pre-roost behaviour of flying over the roosting site just before or after sunset (Satheesan \& Rao 1990; Ganesh \& Kannaiah 1991). Most of the harriers roosted on the ground in tall grass $(>100 \mathrm{~cm})$, while some roosting spots were in areas with short grass $\left(c^{\prime} 40-60 \mathrm{~cm}\right)$ and on bare patches too.

Rahmani and Manakadan (1986) reported a large roost of harriers near Rollapadu comprising an estimated 800-1000 individuals. The large numbers of harriers indicate that the grassland in northern Secunderabad is an important assembly site for roosting and gathering of harriers over a few days before they finally depart on their migratory journey.

\section{Acknowledgements}

We thank Dr. V. Nagulu, and the Head, Department of Zoology for encouragement and facilities. We also acknowledge the Senior Research Fellowships granted to us by CSIR, New Delhi.

\section{References}

Ganesh, T. and P. Kannaiah (1991). Calls of harriers (Circus spp.) near Hyderabad, Andhra Pradesh. J. Bombay nat. Hist. Soc. 88(3): 448.

Kannaiah, P. and T. Ganesh (1995). Importance of kanchas in bird conservation. Mayura 12: 74-81.

Rahmani, A.R.and R. Manakadan (1986). A large roost of harriers in Andhra Pradesh, India. J. Bombay nat. Hist. Soc. 83(Suppl.): 203204.

Satheesan, S.M. and P. Rao (1990). Roosting and feeding of harriers in Secunderabad, Andhra Pradesh. J. Bombay nat. Hist. Soc. 87(1): 143.

Table 1. Estimated numbers of individuals of harriers observed roosting in a grassland in northern Secunderabad on 17 December 1999.

\begin{tabular}{|c|c|c|}
\hline \multirow[t]{2}{*}{ Species } & \multicolumn{2}{|c|}{ Estimated number of individuals } \\
\hline & Minimum & Maximum \\
\hline Pallid Harrier (Circus macrurus) & 220 & 280 \\
\hline Montagu's Harrier (Circus pygargus) & 180 & 250 \\
\hline Pied Harrier (Circus melanoleucos) & 100 & 120 \\
\hline Eurasian Marsh Harrier (Circus aeruginosus) & 70 & 80 \\
\hline Total & 570 & 730 \\
\hline
\end{tabular}

